Reprinted with permission from: Weed Technology. 1994. 8:58-63.

Published and copyrighted by: Weed Science Society of America, http://www.wssa.net

\title{
Leafy spurge (Euphorbia esula) control with fall-applied imazapyr, imazaquin, and imazethapyr ${ }^{1}$
}

\author{
ROBERT A. MASTERS, ROBERT N. STOUGAARD, and SCOTT J. NISSEN \\ Range Sci., U.S. Dep. Agric., Agric. Res. Ser. Asst. Prof. and Asst. Prof., Dep. Agron., Univ. NE, Lincoln, NE 68583. \\ Current address of R. N. Stougaard: Northwest Agric. Res. Cent. Kalispell. MT 59901.
}

\begin{abstract}
:
Imazapyr, imazaquin, and imazethapyr were evaluated for control of leafy spurge. Herbicides were applied at 70, 140, and $280 \mathrm{~g}$ ae/ha in Fall 1989, 1990, or 1991 on a sub-irrigated meadow near Ainsworth, NE and a tallgrass prairie near Columbus, NE. Imazapyr, imazaquin, imazethapyr at $280 \mathrm{~g} /$ ha controlled leafy spurge 58, 82 and 73\%, respectively, 9 months after treatment (MAT) at Ainsworth. Leafy spurge control averaged 49\% 9 MAT at Columbus where $280 \mathrm{~g} /$ ha of the imidazolinone herbicides were applied. Leafy spurge yields were reduced at Ainsworth by 29 and 78\% where the imidazolinones were applied at 140 and $280 \mathrm{~g} / \mathrm{ha}$. By $11 \mathrm{MAT}$, leafy spurge control on areas treated with $280 \mathrm{~g} /$ ha declined to less than $60 \%$ at Ainsworth and $10 \%$ at Columbus. Perennial forage grass yields at both sites were generally unaffected by imazaquin or imazethapyr, but imazapyr at $280 \mathrm{~g} /$ ha reduced yields by 69 and $44 \%$ at Ainsworth and Columbus, respectively. Imidazolinone herbicides applied in the fall partially controlled leafy spurge, but did not increase perennial forage grass yields.
\end{abstract}

\section{Nomenclature:}

Imazapyr, ( \pm )-2-[4,5-dihydro-4-methyl-4-(1-methylethyl)-5-oxo-1 $\mathrm{H}$-imidazol-2-yl]-3-pyridinecarboxylic acid; imazaquin, 2-[4,5-dihydro-4-methyl-4-(1-methylethyl)-5-oxo-1 $H$-imidazol-2-yl]-3-quinolinecarboxylic acid; imazethapyr, 2-[4,5-dihydro-4-methyl-4-(1-methylethyl)-5-oxo-1H-imidazo1-2-yl]-5-ethyl-3-pyridinecarboxylic acid; Leafy spurge, Euphorbia esula L. \#² EPHES.

\footnotetext{
${ }^{1}$ Received for publication July 22,1993 and in revised form Nov. 29, 1993. Contr. no. 10156, Agric. Res. Div., Univ. Nebraska, Lincoln, and the USDA-ARS.

${ }^{2}$ Letters following this symbol are a WSSA-approved computer code from Composite List of Weeds, Revised 1989. Available from WSSA, 1508 West University Ave., Champaign, IL 61821-3133.
}

Page 1 of 10 


\section{Additional index words:}

Rangeland, perennial grasses, imidazolinones, perennial weed control, EPHES.

\section{Introduction}

Leafy spurge is a competitive and widespread perennial weed on rangeland in the northern Great Plains (20). It is rapidly becoming a major pest on grasslands in Nebraska and other central Great Plains states (11). Ranchers view this weed as a significant threat because it reduces the quality and productivity of the grassland resource upon which livestock enterprises rely. Leafy spurge reduces rangeland carrying capacity by competing with desirable forages and rendering infested areas undesirable to cattle (7). Leafy spurge threatens grassland communities by displacing native species (3), thereby reducing plant and animal diversity.

Leafy spurge is a successful adventive species because of the absence of natural enemies and its ability to reproduce by seed and from adventitious buds on the roots and crowns (15). Seed dispersal mechanisms, high seed visibility and longevity, and rapid seedling development enable new infestations to become easily established. Prolific vegetative reproduction and abundant energy reserves in the extensive root system maintain long-lived, dense leafy spurge infestations (15). The capacity to produce new shoots from buds on the crowns and roots contributes to the resistance of this species to chemical and mechanical treatments (14).

Picloram (4-amino-3,5,6-trichloro-2-pyridinecarboxylic acid) and 2,4-D [(2,4-dichlorophenoxy) acetic acid] have traditionally been used to control leafy spurge on rangeland (8). Annual fall and spring treatments of 2,4-D are recommended to reduce leafy spurge seed production, but do not kill established plants (10). Picloram at $2.2 \mathrm{~kg} / \mathrm{ha}$ controls leafy spurge for 24 to 36 mo when applied in the fall (1). The high cost of this treatment limits its use to small infestations.

The imidazolinones are a relatively new family of herbicide chemistry that have not been extensively evaluated for leafy spurge control or forage grass tolerance. Imazethapyr is tolerated by a number of forage legumes (21) and, therefore, could provide an advantage over using 2,4-D and picloram when controlling leafy spurge where desirable legumes are present. Imazapyr is registered for PRE and POST total vegetation control and imazaquin and imazethapyr are registered for PPI, PRE, or POST control of annual broadleaf and grass weeds in soybeans (Glycine max L.). The imidazolinones were shown to have activity on leafy spurge $(12,18)$. The objective of this study was to determine the response of leafy spurge and associated vegetation to imazapyr, imazaquin, and imazethapyr applied in the fall at $280 \mathrm{~g}$ ae/ha and lower rates. 


\section{Materials and Methods}

Experiments were initiated in 1989 at Ainsworth, NE and in 1990 at Columbus, NE. The experiments were repeated in 1991 at both sites. The Ainsworth site was a subirrigated meadow that was hayed annually in mid-July for several years before this study was conducted. Sub-irrigated meadows are common in the Sand Hills rangeland of $\mathrm{Ne}-$ braska and are a valuable forage resource. The water table on sub-irrigated meadows fluctuates on average from $15 \mathrm{~cm}$ above the soil surface during wet years to $75 \mathrm{~cm}$ below the soil surface in dry years (5). The Columbus site was a tallgrass prairie with a management history of moderate to heavy continuous grazing by cattle during the spring and summer. Cumulative precipitation was 55\% below the long-term average at Ainsworth in 1989, but similar to or greater than the long-term average at both sites in 1990, 1991, and 1992 (Figure 1).

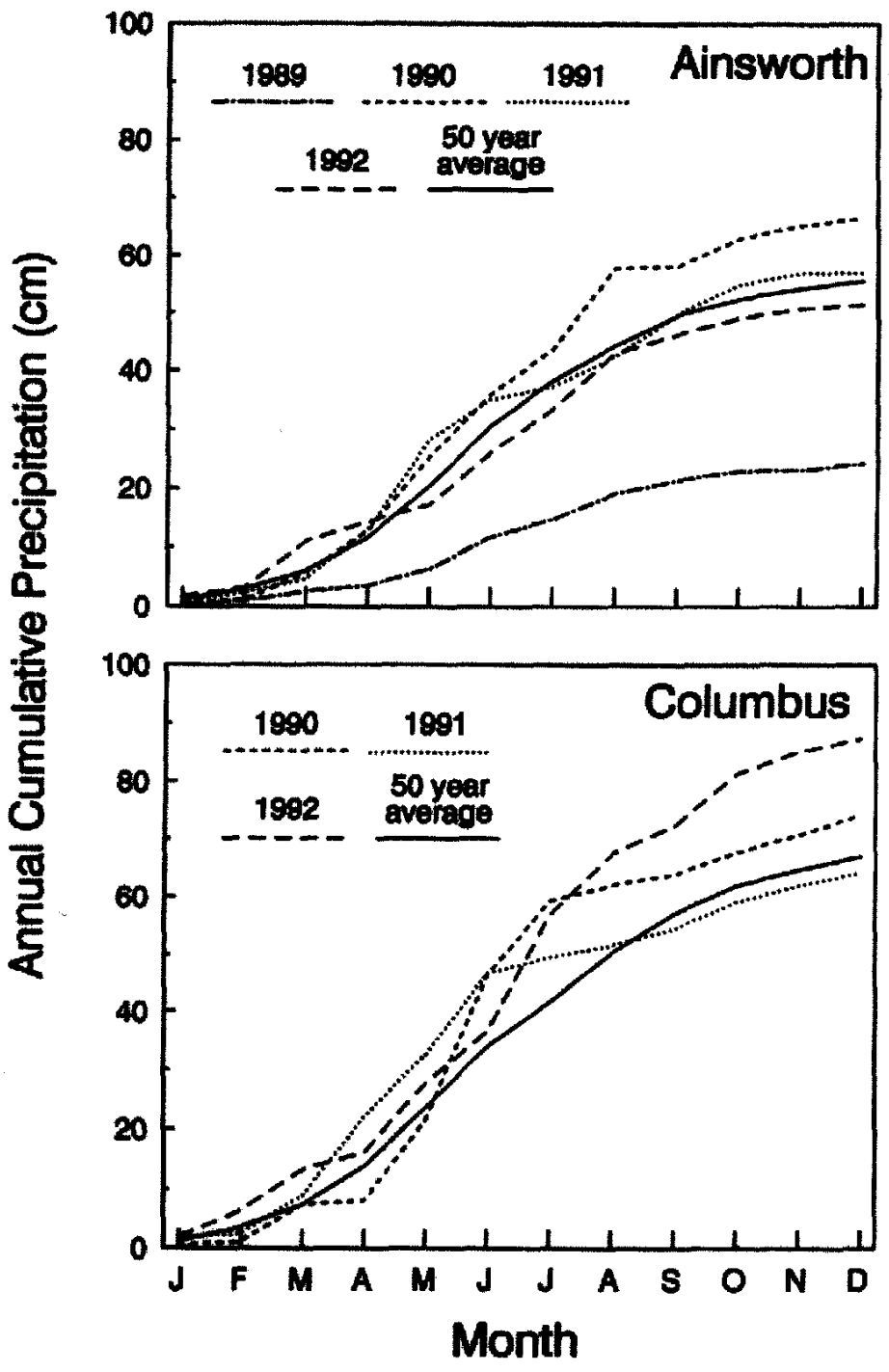

Figure 1. Annual cumulative precipitation during the study and long-term (50-yr) average annual cumulative precipitation at Ainsworth and Columbus, NE. 
Soil texture and organic matter content were different at each site. The soil at Ainsworth was a Tryon loamy fine sand (mixed, mesic, Typic Psammaquent) with $1.7 \%$ organic matter and $\mathrm{pH}$ 6.6. In contrast, the soil at Columbus was a Nora silty clay loam (mixed, mesic, Udic Haplustoll) with 5.6\% organic matter and pH 6.7.

Kentucky bluegrass (Poa pratensis L.) and smooth bromegrass (Bromus inermis L.) were the dominant grasses at Ainsworth. Big bluestem (Andropogon gerardii Vitman var. gerardii Vitman) was the dominant grass and switchgrass (Panicum virgatum L.) and little bluestem [Schizachyrium scoparium (Michx.) Nash] were common at Columbus. Leafy spurge stands were uniform at both sites with an average stand density of 128 stems per $\mathrm{m}^{2}(\mathrm{SE}=5, n=50)^{3}$ at Ainsworth and 145 stems per $\mathrm{m}^{2}(\mathrm{SE}=7, n=54)$ at Columbus.

Sites were not grazed or hayed for the duration of the study. Sites were burned in early April 1990, 1991, and 1992 to remove standing dead vegetation that had accumulated during the previous growing season. Dead vegetation was burned to reduce interference with vegetation sampling and to facilitate evaluation of herbicide treatment efficacy. The potential for damage to leafy spurge and grasses by the fire at both sites was minimized by burning when shoots of these plants were beginning to emerge.

A three by three factorial experiment in a randomized complete block design with one non-treated check per replication outside the factorial was established each year at each site with four replications per treatment combination. Imazapyr, imazaquin, and imazethapyr at 70, 140, and $280 \mathrm{~g} /$ ha were applied on Sept. 3, 1989 and Sept. 27, 1991 at Ainsworth and Sept. 11, 1990 and Sept. 30,1991 at Columbus. Dates in the fall were chosen as the time for herbicide treatments because efficacy of other foliar and soil-active herbicides was maximized when applied to leafy spurge during the fall (1).

Herbicide rates used in this study were selected to address our concerns about potential leafy spurge control and forage grass tolerance. Imazapyr is usually applied either PRE or POST at 0.6 to $1.7 \mathrm{~kg} / \mathrm{ha}$ for control of a broad spectrum of broadleaf and grass weeds (2). We selected $280 \mathrm{~g} /$ ha to be the highest rate used in this study because we found that imazapyr at 560 and $840 \mathrm{~g} /$ ha severely suppressed forage grasses in preliminary experiments (18). Lower herbicide rates used in this study were selected because they were similar to the rates of imazaquin and imazethapyr used for PRE and POST weed control in row crops.

Leafy spurge shoots were at the vegetative to post-flowering phenological stage of development when treated, and plant height was between 50 and $70 \mathrm{~cm}$. Herbicide treatments were applied to previously untreated plots each year at each study site. Herbicides were applied at a speed of $3 \mathrm{~km} / \mathrm{h}$ with a tractor-mounted compressed air sprayer. A nonionic surfactant ${ }^{4}(0.25 \% \mathrm{v} / \mathrm{v})$ was included in the spray solution. The sprayer delivered $180 \mathrm{~L} /$ ha at $280 \mathrm{kPa}$ to 5 - by 8 -m plots. The sprayer boom was equipped with stainless steel extended pressure range flat fan XR11002 nozzle tips.

\footnotetext{
${ }^{3}$ Abbreviations: SE, standard error of the mean; $n$, sample size; MAT, months after treatment.

${ }^{4}$ X-77, Valent U.S.A. Corp., 1333 N. California Blvd., Walnut Creek, CA 94596.
}

Page 4 of 10 
Herbicide efficacy was determined by visually rating leafy spurge control on a scale of $0 \%$ (no control) to $100 \%$ (complete control). Control was rated about 9 and 11 mo after treatment (MAT) on June 29 and Aug. 23, 1990 and June 9 and Aug. 6, 1992 at Ainsworth. Corresponding dates at Columbus were June 6 and Aug. 14, 1991 and June 6 and Aug. 9, 1992. Two observers independently estimated leafy spurge control for each plot on each evaluation date and the ratings were averaged. Visual ratings were adjusted to provide a more conservative estimate of leafy spurge control. In each block, the control rating given the nontreated check plot was subtracted from ratings assigned to herbicidetreated plots. The control rating for the nontreated check plots was then set at $0 \%$. Visual ratings represented an integration of leafy spurge stand density reduction and height suppression.

Herbaceous vegetation was clipped within two $0.25-\mathrm{m}^{2}$ quadrats that were randomly placed in the center 3- by 6-m area in each plot. Vegetation samples were separated into leafy spurge, perennial grass, and broadleaf plant (herbaceous dicots excluding leafy spurge) components, oven-dried at $60 \mathrm{C}$ for $72 \mathrm{~h}$, and weighed. Vegetation was harvested about 10 MAT on June 27, 1990 and June 29, 1992 at Ainsworth and on June 24, 1991 and June 25, 1992 at Columbus. Perennial grasses and broadleaf plants were not separated by species during sampling because their non-uniform distribution made it difficult to assess individual species response to herbicide treatments. Combining species within these two categories allowed the objective of determining overall response of perennial grasses and broadleaf plants to the herbicide treatments to be accomplished.

Data from Ainsworth and Columbus sites were analyzed separately because error variances were not homogeneous according to Bartlett's test (17). Univariate analysis of variance and a plot of residuals indicated that the variances associated with percent leafy spurge control and leafy spurge, perennial grass, and broadleaf dry matter yield data within each site and across years were normally distributed and that no transformation of the data was necessary. Control and dry matter yield data were combined across years and analyzed. Single degree of freedom orthogonal contrasts of interest were partitioned to evaluate response of measured vegetation parameters to herbicides and herbicide rates. Contrasts were determined to be significant at the $\mathrm{P} \leq 0.05$ level of probability. Control and yield parameters were compared using Fisher's protected LSD $(a=0.05)$.

\section{Results and Discussion}

Leafy spurge control and yield. Leafy spurge control at Ainsworth was influenced by herbicides and herbicide rates (Table 1). In contrast, herbicide rate and not specific herbicide applied influenced leafy spurge control at Columbus (Table 2). At Ainsworth, imazaquin at $280 \mathrm{~g} / \mathrm{ha}$ controlled leafy spurge $82 \% 9$ MAT and imazapyr only controlled leafy spurge $58 \%$ when applied at the same rate (Table 1). Control of leafy spurge with $140 \mathrm{~g} / \mathrm{ha}$ of imazaquin was not significantly different than control with $280 \mathrm{~g} / \mathrm{ha}$ of imazapyr and imazethapyr. The imidazolinone herbicides at $280 \mathrm{~g} /$ ha controlled leafy spurge 49\% 9 MAT at Columbus. Leafy spurge control was less than 10\% 9 MAT at both sites where $70 \mathrm{~g} / \mathrm{ha}$ of the imidazolinone herbicides was applied.

Page 5 of 10 
Table 1. Leafy spurge control at Ainsworth, NE 9 and 11 mo after treatment with imazapyr, imazaquin, and imazethapyr in the fall of 1989 and $1991^{\mathrm{a}}$.

\begin{tabular}{lccc}
\hline \multirow{2}{*}{ Herbicide } & Rate & \multicolumn{2}{c}{ Evaluation date (months after treatment) } \\
\cline { 2 - 4 } Non-treated & $\mathrm{g}$ ae/ha & 0 & 11 \\
Imazapyr & 0 & 9 & 0 \\
& 70 & 15 & 5 \\
Imazaquin & 140 & 58 & 12 \\
& 280 & 5 & 25 \\
& 70 & 56 & 13 \\
Imazethapyr & 140 & 82 & 20 \\
& 280 & 6 & 57 \\
& 70 & 31 & 3 \\
& 140 & 73 & 3 \\
& 280 & 17 & 29 \\
\hline
\end{tabular}

${ }^{a}$ Control ratings averaged across years for each evaluation date.

Table 2. Leafy spurge control at Columbus, NE and leafy spurge dry matter yield at Ainsworth and Columbus, NE after treatment with imazapyr, imazaquin, and imazethapyr in the fall.

\begin{tabular}{|c|c|c|c|c|}
\hline \multirow[b]{3}{*}{$\overline{\text { Rate }}$} & \multicolumn{4}{|c|}{ Leafy spurge control $^{\mathrm{a}}$} \\
\hline & \multicolumn{2}{|c|}{$\begin{array}{c}\text { Evaluation date } \\
\text { (mo after treatment) }\end{array}$} & \multicolumn{2}{|c|}{ Leafy spurge dry matter yield ${ }^{\mathrm{b}}$} \\
\hline & 9 & 11 & Ainsworth $^{\mathrm{c}}$ & Columbus $^{\mathrm{d}}$ \\
\hline g ae/ha & \multicolumn{2}{|c|}{-------- \% -------- } & \multicolumn{2}{|c|}{------kg/ha----- } \\
\hline 0 & 0 & 0 & 1360 & 1160 \\
\hline 70 & 0 & 8 & 1660 & 1150 \\
\hline 140 & 16 & 7 & 970 & 1070 \\
\hline 280 & 49 & 9 & 300 & 830 \\
\hline $\operatorname{LSD}(0.05)$ & 9 & NS & 380 & NS \\
\hline
\end{tabular}

${ }^{\mathrm{a}}$ Control ratings averaged across herbicides and years for each evaluation date.

${ }^{b}$ Yield estimates obtained 10 mo after treatment and averaged across herbicides and years for each site.

${ }^{c}$ Herbicides applied in Fall 1989 and 1991.

${ }^{\mathrm{d}}$ Herbicides applied in Fall 1990 and 1991.

Leafy spurge control with $280 \mathrm{~g} /$ ha of the imidazolinones was not sustained during the entire growing season the year after treatment at either site. Leafy spurge control by 11 MAT declined to $57 \%$ where $280 \mathrm{~g} /$ ha of imazaquin was applied and to less than $30 \%$ where imazapyr and imazethapyr were applied at Ainsworth. At Columbus, leafy spurge control was less than $10 \%$, regardless of herbicide treatment by 11 MAT (Table 2).

Leafy spurge yield was reduced by the imidazolinones at Ainsworth, but not at Columbus (Table 2). In contrast to leafy spurge control, leafy spurge dry matter yield at 
Ainsworth was influenced by rate of herbicides applied, but not specific herbicides applied. Treatment with the imidazolinones at $280 \mathrm{~g} / \mathrm{ha}$ and $140 \mathrm{~g} / \mathrm{ha}$ reduced leafy spurge yield by $78 \%$ and $29 \%$, respectively, 10 MAT compared to non-treated plots. There was no evidence of leafy spurge yield reductions at Columbus 10 MAT with the imidazolinones.

Abnormal proliferation of leafy spurge shoots was observed the spring following fall treatment with the imidazolinones at $280 \mathrm{~g} / \mathrm{ha}$. This observation suggests that the imidazolinone herbicides were either translocated or directly absorbed from the soil solution into leafy spurge adventitious shoot buds. Apparently, the herbicides interfered with adventitious bud dormancy mechanisms and caused quiescent buds to become active. Similar effects have been observed with fall-applied glyphosate [N-(phosphonomethyl)glycine] on leafy spurge (13).

Soil characteristics unique to each site may explain the variation in leafy spurge suppression observed at Ainsworth and Columbus. Soil clay and organic matter content influence availability and efficacy of the imidazolinones. Stougaard et al. (19) determined that the efficacy of imazaquin and imazethapyr was greater in sandy soil than in silty clay loam soil. Imazaquin adsorption was positively correlated with soil clay and organic matter content (6). Differences in soil texture and organic matter content may account for increased leafy spurge control and yield reductions at Ainsworth where the soil was a fine sand with an organic matter content of $1.7 \%$ as compared to Columbus where the soil was a silty clay loam and had an organic matter content of $5.6 \%$.

Grass and broadleaf plant response. The perennial grasses responded to herbicides and rate of herbicides applied at both sites (Table 3). The year by herbicide treatment interaction was significant $(\mathrm{P}=0.01)$ for forage grass yields at Ainsworth and the main ef-

Table 3. Forage grass dry matter yield at Columbus and Ainsworth, NE 10 mo after treatment with imazapyr, imazaquin, and imazethapyr in the fall.

\begin{tabular}{lcccc} 
& & & \multicolumn{2}{c}{ Ainsworth } \\
\cline { 4 - 5 } Herbicide & Rate & Columbus $^{\mathrm{a}}$ & 1990 & 1992 \\
\hline \multirow{3}{*}{ Non-treated } & $\mathrm{g}$ ae/ha & $--------------\mathrm{kg} / \mathrm{ha}---------------$ \\
Imazapyr & 0 & 2320 & 2570 & 1630 \\
& 70 & 2560 & 2150 & 1350 \\
Imazaquin & 140 & 1900 & 1260 & 1200 \\
& 280 & 1290 & 790 & 1240 \\
Imazethapyr & 70 & 2410 & 2160 & 1360 \\
& 140 & 2690 & 2820 & 1650 \\
& 280 & 3200 & 2600 & 1210 \\
& 70 & 2560 & 1720 & 1300 \\
& 140 & 2590 & 2990 & 1280 \\
& 280 & 2930 & 2630 & 1480 \\
\hline
\end{tabular}

${ }^{\text {a } D r y ~ m a t t e r ~ y i e l d ~ e s t i m a t e s ~ a v e r a g e d ~ a c r o s s ~ y e a r s . ~ H e r b i c i d e s ~ a p p l i e d ~ i n ~ f a l l ~ o f ~} 1990$ and 1991. 
teraction was significant $(\mathrm{P}=0.01)$ for forage grass yields at Ainsworth and the main effect of herbicide treatment was significant $(\mathrm{P}=0.02)$ for grass yields at Columbus. Therefore, yield data from Ainsworth were separated by years and data from Columbus were combined across years. Generally, perennial grass yields were unaffected by rate of imazaquin or imazethapyr 10 MAT each year at both sites, except at Ainsworth in 1990 where imazethapyr had been applied at $70 \mathrm{~g} / \mathrm{ha}$. There is no evidence in the literature of imazethapyr adversely affecting either Kentucky bluegrass or smooth bromegrass when applied at this low rate in the fall.

Grass yields were reduced by imazapyr at Ainsworth in 1990 and Columbus (Table 3). Imazapyr at 140 and $280 \mathrm{~g} /$ ha reduced grass yields at Ainsworth in 1990 by an average of 51 and $69 \%$, respectively, compared to yield from the areas not treated with herbicide. At Columbus, imazapyr at $280 \mathrm{~g} /$ ha reduced grass yields by $44 \%$ compared to nontreated areas.

The lack of grass yield reductions following treatment with imazapyr at Ainsworth in 1992 as compared to 1990 may be the result of differences in distribution and amount of precipitation within 6 MAT. From time of herbicide application in Oct. 1989 through Mar. 1990 there was a total of $3.3 \mathrm{~cm}$ of precipitation, while during that same period during 1991 and $19927.2 \mathrm{~cm}$ of precipitation was received (Figure 1). A low amount of precipitation during the 1989 to 1990 period could have moved the imazapyr into a relatively shallow portion of the sandy soil profile and increased the concentration of herbicide to which Kentucky bluegrass and smooth bromegrass roots were exposed. In contrast, increased precipitation in 1991 to 1992 could have diluted imazapyr concentration in the sandy soil by moving the herbicide deeper into the soil profile and beyond the root zone of the Kentucky bluegrass and smooth bromegrass.

Forage grass responses at Columbus and Ainsworth were generally consistent with grass specificity of these herbicides. The dominant grasses at the sites are not listed as species controlled on imazaquin and imazethapyr product labels. In contrast, imazapyr at 560 to $840 \mathrm{~g} /$ ha controls Kentucky bluegrass and smooth bromegrass and at 1.12 to 1.68 $\mathrm{kg} / \mathrm{ha}$ controls big bluestem (2). The rates of imazapyr listed by Beardmore et al. (2) to control these grasses are greater than imazapyr rates that suppressed grass yields in our study. Differential metabolism of the imidazolinones by the grasses may explain the observed increased susceptibility of the grasses to imazapyr as compared to imazaquin or imazethapyr. The selectivity of the imidazolinone herbicides is influenced by the capacity of the plant to metabolize the herbicide to an immobile and/or a nonphytotoxic metabolite (16).

Control of leafy spurge by imazaquin and imazethapyr at $280 \mathrm{~g} / \mathrm{ha} 9 \mathrm{MAT}$ (Table 1) did not increase perennial grass yield 10 MAT (Table 3). This may be explained by differential susceptibility of individual grass species to the imidazolinones at both sites that resulted in a reduction in the overall yield. Susceptibility to the herbicides cannot be determined from this study because individual grass species were combined during sampling. Absence of a positive grass yield response may result from the incomplete control of leafy spurge with the imidazolinones. By 10 MAT leafy spurge regrowth was present even on areas that had received the $280 \mathrm{~g} /$ ha herbicide treatments. Competition between the recovering leafy spurge and perennial grasses may have been sufficient to negate any increase in grass yield despite initial control of leafy spurge at both sites. A positive grass

Page 8 of 10 
yield response following herbicide treatment may require suppression of not only leafy spurge top growth, but also the roots and crowns.

Studies conducted in North and South Dakota found that 2,4-D, picloram, and dicamba (3,6-dichloro-2- methoxybenzoic acid) provided fair to good control of leafy spurge and increased forage grass yields $(4,9)$. Competition between leafy spurge and perennial grasses was not quantified. Grass yield in those studies was measured following 5 to $6 \mathrm{yr}$ of annual herbicide treatments; whereas, in our study, grass yield was measured the year following a single treatment with the imidazolinones.

Yield of broadleaf plants (excluding leafy spurge) was unaffected $(\mathrm{P} \geq 0.05)$ by treatment with the imidazolinones at both sites. The quantity of broadleaf plants produced during this study ranged from an average of 0 to $12 \mathrm{~kg} / \mathrm{ha}$ at Ainsworth and 8 to $81 \mathrm{~kg} / \mathrm{ha}$ at Columbus. Vegetation sampling techniques used may not have been sensitive enough to detect responses of the broadleaf plants to the imidazolinones given the non-uniform distribution and low quantity of broadleaf plants at the study sites. Few broadleaf plants were present because past management practices included annual treatment with picloram or 2,4-D to control leafy spurge. Most likely, picloram or 2,4-D applied over the longterm influenced the botanical composition of the plant communities at each site by selectively controlling or suppressing susceptible broadleaf plants.

In summary, fall-applied imazapyr, imazaquin, or imazethapyr at $280 \mathrm{~g} / \mathrm{ha}$ partially controlled leafy spurge for 9 MAT, but leafy spurge recovery was evident by 11 MAT. Efficacy of the imidazolinones appeared to be influenced by soil texture and/or organic matter content because leafy spurge suppression was greater at Ainsworth where the soil was sandy with low organic matter as compared to Columbus where the soil was a silty clay loam with greater organic matter. The control achieved with the imidazolinone herbicides 9 MAT appears to compare favorably with control observed in other experiments (8) with picloram at low rates or 2,4-D applied in the fall or spring. Additional research is needed to determine whether repeated annual fall-applied treatments of imidazolinone herbicides will reduce the size and density of established leafy spurge infestations and what effect the imidazolinones have on individual forage grass and legume species that grow in association with leafy spurge.

\section{Acknowledgments}

The authors thank Kevin Grams, Mack Thompson, Ken Carlson, Joe Shuh, and Sid Salzman for their assistance and American Cyanamid and the Nebraska Leafy Spurge Working Task Force for partial funding of this study.

\section{Literature Cited}

1. Alley, H. P. and C. G. Messersmith. 1985. Chemical control of leafy spurge. p. 65-78 in A. K. Watson, ed. Leafy Spurge. Weed Sci. Soc. Am. Monogr. 3., Champaign, IL.

2. Beardmore. R. A., R. Hart, R. Iverson, M. A. Risley, and M. Trimmer. 1991. Imazapyr herbicide. p. 211-227 in D. L Shaner and S. L. O'Connor, eds. The Imidazolinone Herbicides. CRC Press, Inc., Boca Raton, FL.

Page 9 of 10 
3. Belcher, J, W. and S. D. Wilson. 1989. Leafy spurge and the species composition of a mixed-grass prairie. J. Range Manage. 42:172-175.

4. Gylling, S. R. and W. E. Arnold. 1985. Efficacy and economics of leafy spurge (Euphorbia esula) control in pasture. Weed Sci. 33:381-385.

5. Kaziula, M. 1989. Soil associations and series. p. 58-66 in A. Bleed and C. Flowerday, eds. An Atlas of the Sand Hills. Resource Atlas No. 5. Univ. Nebraska Press. Lincoln.

6. Loux. M. M., R. A. Liebl, and F. W. Slife. 1989. Adsorption of imazaquin and imazethapyr on soils, sediments, and selected absorbents. Weed Sci. 37:712-718.

7. Lym, R. G, and D. R. Kirby, 1987. Cattle foraging behavior in leafy spurge (Euphorbia esula)-infested rangeland. Weed Technol. 1:314-318.

8. Lym. R.G. and C. G. Messersmith. 1985. Leafy spurge control with herbicides in North Dakota: 20year summary. J. Range Manage. 38:149-154.

9. Lym, R. G. and C. G. Messersmith. 1985. Leafy spurge control and improved forage production with herbicides. J. Range Manage. 38:386-391.

10. Lym, R. G. and C. G. Messersmith. 1987. Leafy spurge control and herbicide residue from annual picloram and 2,4-D application. J. Range Manage. 40:194-198.

11. Masters, R. A. 1991. Leafy spurge: Threat to central plains grasslands. p. 101-106 in D. Smith and C. Jacobs, eds. Proc. Twelfth North American Prairie Conf. Cedar Falls, IA.

12. Masters, R. A., R. N. Stougaard, and S. J. Nissen. 1990. Leafy spurge response to rate and time of application of imidazolinone herbicides. Proc. North Cent. Weed Sci. Soc. 45:65.

13. Maxwell. B. D., M.E. Foley, and P.K. Fay. 1987. The influence of glyphosate on bud dormancy of leafy spurge (Euphorbia esula). Weed Sci. 35:6-10.

14. Messersmith, C. G., R. G. Lym, and D. S. Galitz. 1985. Biology of leafy spurge. p. $42-56$ in A. K. Watson, ed. Leafy Spurge. Weed Sci. Soc. Am. Monogr. 3., Champaign, IL.

15. Raju, M. V. S. 1985. Morphology and anatomy of leafy spurge. P. 26-41 in A. K. Watson. ed. Leafy Spurge. Weed Sci, Soc. Am. Monogr. 3., Champaign, IL.

16. Shaner, D. L. and N. M. Mallipudi. 1991. Mechanisms of selectivity of the imidazolinone herbicides. P. 91-102 in D. L. Shaner and S. L. O'Connor, eds. The Imidazolinone Herbicides. CRC Press, Inc., Boca Raton, FL.

17. Steel, R. G. D. and J. H. Torrie. 1980. Some uses of chi-square. p. 469-476 in Principles and Procedures of Statistics. McGraw-Hill Co., New York.

18. Stougaard, R. N., R. A. Masters, and S. J. Nissen. 1990. Leafy spurge control with imidazolinone herbicides. Proc. North Cent. Weed Sci. Soc. 40:64.

19. Stougaard, R. N., P. J. Shea, and A. R, Martin. 1990. Effect of soil type and pH on adsorption, mobility, and efficacy of imazaquin and imazethapyr. Weed Sci. 38:67-73.

20. Watson, A. K. 1985. Introduction-The leafy spurge problem. P. 1-7 in Watson, A. K., ed. Leafy Spurge. Weed Sci. Soc. Am. Monogr. 3., Champaign, IL.

21. Wilson. R. G. 1990. Effect of imazethapyr on six forage legumes. Proc. North Cent. Weed Sci. Soc. 45:64. 